\title{
Market Ethics with Trade in an Edgeworth Box
}

\author{
Steven Suranovic ${ }^{1}$ \\ The George Washington University
}

This paper offers a method for introducing the ethics of markets to economics students, an emphasis that is missing in standard economics texts. The approach uses a pure exchange model to demonstrate how certain ethical principles, such as respecting property, fulfilling promises, and avoiding deception and violence against others, are inherent in all neoclassical models and help to assure the win-win outcome that arises with trade. These lessons are needed to counter false popular impressions that economics and business activities are amoral and to emphasize the importance of social, religious and government institutions that have evolved to inhibit unethical behavior.

\section{INTRODUCTION}

The fundamental assumptions in all neoclassical economic models are that individuals are selfinterested, and rational. They will use all information available to them (in many instances that information will be perfect) and take actions to maximize profit in production and utility in consumption. Homo economicus is the term commonly used to describe individuals with these behavioral characteristics in economic models.

To many people the homo economicus assumption is often viewed with suspicion or derision. BenNer and Putterman (1998) state that "homo economicus is at best amoral, and at worst outright immoral: he will engage in any actions that will benefit him, theft, cheating, and - why not? -- murder, irrespective of their impact on the welfare of others." The popular perception is that economic man is excessively greedy and will do anything in his power to improve his lot. He has no "other-regarding" or altruistic preferences. In short, he is not a very pleasant person. (Snower, 2014; Ubel, 2014)

Although economics praises self-interest as beneficial to the workings of the economy and society, many social observers consider self-interest to be tantamount to greed; an immoral trait that would best be supplanted by altruistic behaviors. Hollywood movies reinforce the perception of greed in economic and business dealings by regularly portraying business as an evil force in the world; one where money-making motives enable exploitation, theft and harm to others. In the classic movie Wall Street (1987) Michael Douglas' character makes an impassioned speech explaining why "greed, for lack of a better word, is good." This matches the economic notion that self-interest is a positive force. ' However, when Douglas' character is brought down and imprisoned by the end of the movie, popular impressions about greed are vindicated. In the sequel, Wall Street: Money Never Sleeps (2010), Michael Douglas' character, having had a chance to reflect in prison on the errors of his ways, makes another speech in which he criticizes his original "greed is good" perspective.

Because homo economicus is a cornerstone of the entire neoclassical paradigm, students that are new to economics, sometimes quickly infer that economic theory does not contain a moral compass. In 2011 
during the Occupy Wall Street movement, some students at Harvard University boycotted N. Gregory Mankiw's principles of economics course arguing that neoclassical economics had a conservative bias and was not sufficiently sensitive to the injustices in the economic system. This popular sentiment later inspired the CORE-Econ project at Oxford's Institute for New Economic Thinking, intended to provide a more enriching curriculum for introductory economics students. Wendy Carlin, CORE's Director, argued that a change in approach is needed because, "...experimental methods have shown that people are more fair-minded and moral, and less calculating than the so called Economic Man of the textbooks. $" 34$

This paper confronts these perceptions by highlighting that in order for markets to function effectively it is important for individuals to adhere to several ethical constraints. These ethical principles are embedded in the assumptions of economic models and are often presented in the early economics literature; however, they are downplayed so much in introductory textbooks today that it is likely that most students leave their first courses with an unsatisfactory appreciation of the importance of ethics in economics. The fact that business values and economic motivations are viewed so negatively and suspiciously by the general public is one indication that the ethical content of economics is not being adequately conveyed.

In a review of the top introductory microeconomics textbooks, it was found that all of them include some discussion about ethical issues, especially a mention of the importance of property rights and concerns about inequality. ${ }^{5}$ However, in most instances the discussion of these issues was relegated to later chapters or was mentioned in passing. Further, none of the texts convey a complete account of the importance of ethical behavior to a smooth functioning market. In particular they rarely discuss what might happen when the ethical foundations falter. One slight exception is the online textbook created by the Core project, which does emphasize potential inequitable outcomes in markets, however, it does so, not in the context of a standard neoclassical model, but with a model designed to illustrate the potential for inequitable division of the surplus from trade. ${ }^{6}$

Most textbooks have a discussion about market imperfections, or market failures, such as externalities, public goods and common resources and they all suggest how government intervention can be used to correct for these market imperfections. However, none of the texts discuss what Coleman (1985) described as pre-market failures; namely failures in the ethical principles that underpin a functioning market and that are needed in order for markets, let alone perfectly competitive markets, to even be possible. (Skaperdas, 2003).

This paper suggests use of an Edgeworth box diagram depicting a pure exchange model to teach principles of economics students the relevance and importance of ethics in the functioning of the simplest market economy. The paper first highlights what are the foundational ethical principles of a pure exchange market; second, why adherence to this system of ethics can enhance the effectiveness of the market; third, the limits of the homo economicus assumption and why market effectiveness requires restraints on self-interested behavior (in other words, why homo economicus cannot act as brutish as he likes); and fourth, the methods that have been employed, both private and public, to encourage ethical behavior and how they assist in maintaining market effectiveness. With respect to the third point, the paper will demonstrate the critical importance of self-interested behavior to making markets work, but will also show how excessively self-interested behavior - or, greed - can damage market effectiveness. Understanding the boundary between acceptable self-interest and greed is something all students of economics should understand. With respect to the fourth point, this paper will highlight the role of social norms and government in promoting ethical behavior on the part of market participants.

Note that this paper does not consider all aspects of market ethics, but instead focuses only on those ethical principles required to guarantee an effective outcome in the simple process of exchange or trade. Other potential elements of market ethics arise from the implications of competition among firms, the distribution of resources, and the presence of market imperfections. While these issues are important too, they are beyond the scope of this paper. 


\section{INTRODUCING THE EDGEWORTH BOX}

A market is any place where the exchange of goods or services occurs. As such, exchange is the defining, or fundamental, activity of a market. Economists have long used the graphical construction called the Edgeworth box, especially in intermediate economics courses, to teach the basic principles of market exchange. Among its best uses is to demonstrate the principle of Pareto optimality and provide a clear depiction of the conditions in a trading equilibrium. However, pared down to its more fundamental assumptions, the Edgeworth box becomes an instructive instrument in a number of other respects. First, it allows one to demonstrate the basic construction of an economic model and how assumptions impact the conclusions that are reached. Second, by relaxing those assumptions we can demonstrate the ethical underpinnings that help make a simple market function more effectively.

Although the Edgeworth box can be difficult to understand for principles of economics students, the pure exchange model that it describes has fewer assumptions than a completely specified supply and demand model because it describes the simplest element of economic activity. The model can be useful to present as the first economic model in an introductory microeconomics course by de-emphasizing the optimizing solution (saving those details for an intermediate course) and emphasizing instead how each assumption in the model affects the outcome.

For example, assume a world with two agents, Smith and Jones, and two homogeneous goods, apples and oranges. Smith and Jones have perfect information about the goods and about their preferences for the goods. Standard indifference curves can be illustrated incorporating the assumptions that more is better and diminishing marginal utility. As a working example we may assume that Smith is initially endowed with 10 oranges and 0 apples, while Jones is endowed with 10 apples and 0 oranges.

An Edgeworth box for the two individuals is shown in Figure 1. Smith's origin is in the lower left while Jones' is in the upper right and their endowment is at point E. Smith (solid line) and Jones' (dashed line) indifference curves passing through the endowment point E creates a "lens" in the center of the diagram. The lens is an important feature of the graph since any trade that results in an allocation within the lens will put both agents on a higher indifference curve and hence will raise both agents' utility. Trading into the lens is mutually beneficial. 


\section{FIGURE 1 \\ AN EDGEWORTH BOX FOR TWO TRADERS}

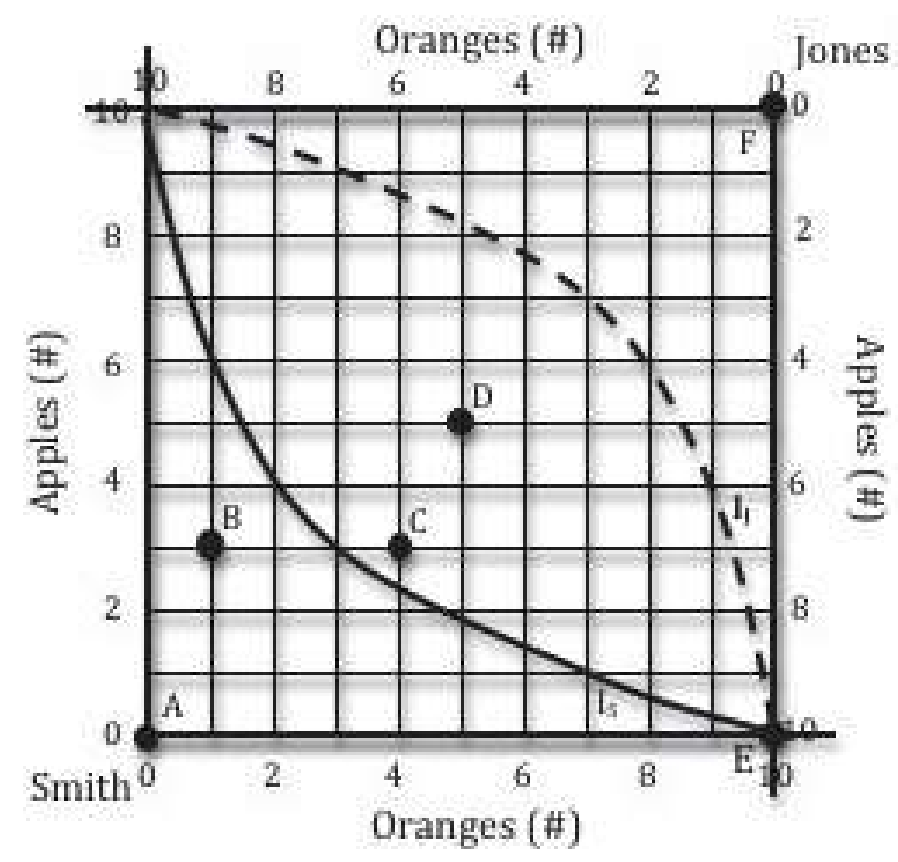

\section{GAINS FROM TRADE}

When Smith and Jones come together and communicate with each other about trading possibilities a "market" is formed. A market can be a physical location such as a farmer's market or a grocery store or it can be a virtual space as when traders meet online at websites like Amazon or eBay. Clear communication will require that the traders share a common language.

The definition of trade is that it is a mutually voluntary exchange, but to get to exchange, trade requires an objective. The standard assumption is to suppose that Smith and Jones try to maximize their utility. However initially it is useful to assume a simpler assumption: namely that Smith and Jones are both self-interested and simply wish to increase their utility.

The implication of this behavioral objective is that any suggested offer that results in a final allocation within the lens (and not on the initial indifference curves) will result in an improvement in utility for both Smith and Jones. Logic dictates that because trade into the lens achieves their objectives it would also be mutually voluntary. There are many ways to state this result: 1) Both agents gain from trade. 2) Trade is a win-win outcome. 3) Trade, or exchange, creates an increase in value, a surplus value. 4) I tell students that trade generates happiness bursts for both Smith and Jones. All of these terms can be used to describe the outcome of mutually voluntary trade, or exchange.

\section{A TRADING EQUILIBRIUM}

With a simple behavioral assumption, such as a desire only to increase utility, any allocation in the lens is a possible outcome (such as points $C$ and $D$ in Figure 1). For example, Jones might propose a trade of 6 oranges for 3 apples (a move to point $C$ in Figure 1) and Smith may simply accept since that raises his utility. However, if we assume traders achieve utility maximums, we can narrow the possible outcomes by recognizing that they will exhaust any potential mutual gains from trade and achieve a Pareto optimal allocation. The set of Pareto optimal points are the points of tangency between 
indifference curves within the Edgeworth box and is shown as the solid line between $\mathrm{P}$ and $\mathrm{O}$ in Figure 2 below. Pigou called this set of outcomes the "range of practicable bargains." (Harsanyi, 1956) With this assumption we can eliminate many outcomes in the lens.

However in order to depict a definitive solution we must imagine an alternative process such as Nash bargaining over the allocation of the surplus value or the presence of an auctioneer seeking a terms of trade to satisfy Walras' law that supply must equal demand for all goods in a final equilibrium. ${ }^{7}$ A final equilibrium can be depicted as a point such as $\mathrm{S}$ in Figure 2.

In summary at this stage, we can say that if Smith and Jones both have perfect knowledge about their preferences over two homogeneous goods of known qualities, if their preferences exhibit diminishing marginal utility and if more is better, and if they trade mutually voluntarily so as to maximize their individual utility after trade, then they will trade to an allocation such as point $\mathrm{S}$ in Figure 2 that is Pareto optimal. The result is mutual gains from trade; that is, both traders benefit and since the gains from trade are exhausted, the outcome is efficient.

FIGURE 2

\section{A TRADING EQUILIBRIUM}

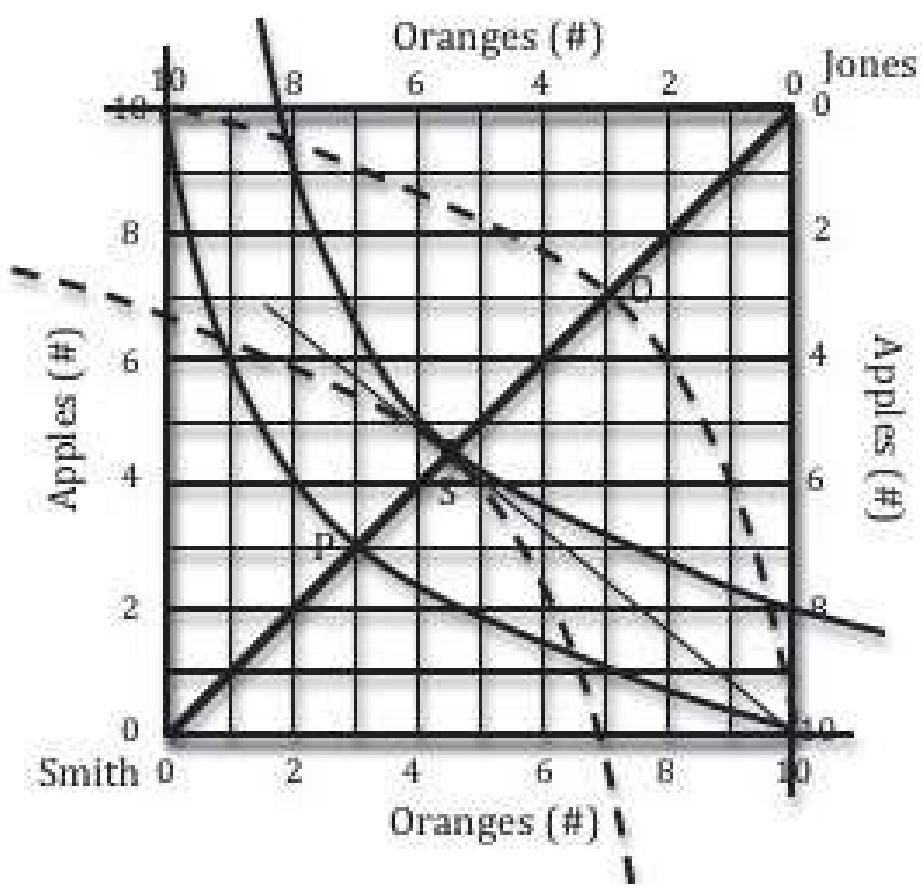

\section{THE IMPLICIT ETHICS IN MARKET EXCHANGE}

The efficient outcome described above is all well and good but it is important to emphasize to students that the conclusions logically follow only when the assumptions hold true. The next important step is to highlight what could happen if one or more of the assumptions do not hold, since, in many instances the assumptions made in models are not satisfied in the real world. Economic models are not perfect representations of the world, instead models simplify the world so that definitive logical conclusions can be drawn. Understanding of economics should be as much about how models work, as it is about how models fail to work when the assumptions are not valid. Indeed, adjusting the assumptions in a model is like running an experiment, in that it allows us to judge the importance of each assumption in reaching the logical conclusion. Relaxing assumptions also provides a better understanding of why the assumption was included in the first place. 


\section{The Importance of Self Interest}

In most instances utility seeking self-interest motivates the desire to trade. To understand the importance of this motivation one can imagine an alternative assumption. If, for example, one or both of the agents had no desire to increase their own utility then one could not assure that any discussion about trading possibilities will actually result in trade. Of course, it is conceivable that Smith or Jones seeks the other good because they wish to give it as a gift to another person. In this case, it is not strictly selfinterest, but their desire to do something good for another, that motivates their participation in a market. For this reason, self-interest may not be absolutely necessary for trade to occur, nonetheless, it seems likely that self-interest (or perhaps more broadly, household interest) is the prime motivator in most trading circumstances. Thus, self-interest to raise one's utility is a sufficient condition to motivate trade. It is worth noting, however, that the motivation to trade, the occurrence of trade and the mutual gains from trade do not require traders to adopt the much stronger assumption of utility maximization.

Second, suppose that Smith wishes to increase his utility though trade, but suppose Jones has grown up in a family that preaches the value of self-sufficiency. Both agents may be self-interested but Jones' interest is better served by relying on his own endowment and thus he prefers not to trade. Jones' indifference curves over the goods may still be relevant, but only under the added assumption that different bundles being compared are acquired independently and not via the dependency of trade. Under this new assumption, the potential surplus value will not arise, because trade would not occur. Because of Jones' preferences he prefers this outcome, but Smith is clearly worse off if he cannot find a trading partner willing to cooperate. Acceptance of utility-seeking self-interest achieved via dependency on trade with others, then, can be characterized as an ethical principle that is also sufficient for a market to function. Another way to say this is that if Smith and Jones agree to cooperate with each other in the pursuit of their self-interest, then they can help each other out through trade. In contrast, a belief in selfsufficiency is non-cooperative and thus implies an alternative ethic that is inconsistent with the operation of a simple market.

However, there are additional ethical principles implicitly hidden within the assumptions listed above; first that trades are mutually voluntary and second that there is perfect information about individual preferences and the nature of the goods.

\section{The Importance of Property}

If Smith is truly intent to maximize his utility and wants to reach the highest utility possible then that outcome would be realized not inside the trading lens, but rather at point F in Figure 1 where Smith gets all of Jones' apples while simultaneously keeping all of his oranges. Jones' utility would fall to zero in this outcome and thus Jones would never agree to it; the outcome could not be obtained mutually voluntarily. But if we inquire whether it is conceivable for this allocation to be realized, the answer is yes.

One method for Smith to achieve the allocation at $\mathrm{F}$ is by the use of violence or force: Smith could hit Jones with a club, knock him out cold, and take all his apples. Another possibility is with a coercive threat: Smith could point a gun at Jones, threaten to shoot him if he doesn't give him his apples, thereby forcing compliance. A third possibility is by stealth: if Jones leaves his goods momentarily unattended, Smith could surreptitiously put Jones' apples into his own bag. No one would hesitate to call any of these actions "theft." Smith is clearly stealing the apples to achieve his maximum utility. However, in calling this theft, certain assumptions are implicitly being made. ${ }^{8}$

First we are assuming that Jones owns the apples. They belong to him. They are his possession or property. Theft only has meaning if we first assume a property system in which individuals are assumed to own their possessions. At its most basic level, property requires the acceptance on the part of the participants that a possession gives the privilege of its use. It's a belief that what's mine is mine to use as I please, and what's yours is yours. As such, the taking of what's yours as mine (theft), is a violation of a system of property. The property principle is cooperative because both agents must accept the principle together and be willing to depend on each other through trade for mutual advantage. ${ }^{9}$

The respect for personal property may reasonably extend to property in one's own body. One of the greatest fears that people have is the concern about physical injury. While injury can arise when a thief 
steals something, injury can also occur without the intent to steal. For example, a criminal may be motivated by anger and merely intent on causing harm to others. Alternatively a terrorist group may cause injury and death by exploding a bomb in a public place. These actions put individuals at risk of injury or death. They can also affect the functioning of market activity if the well-being of individuals is threatened either at the market location or while the persons or goods are in transit to the market location. Thus, it is important for traders to feel safe and secure when they travel to, and participate in, the market. If physical safety is sufficiently threatened they may not go to the market and trade will not occur. In other words, without such respect or protections for private and personal property, the market may not even materialize.

The mutually voluntary assumption also implies an expression of freedom for the individual that is closely connected to individual property rights. If a terms of trade is suggested that would lead to a reduction in welfare for one of the agents, the mutually voluntary assumption implies that an individual is free to refrain from trade. If a participant wants to trade she can, but if she prefers not to, then she can hold onto her original endowment. There can be no coercion to trade on unacceptable terms. Coercion of any sort would require the power of force, or threat of force, against the weaker of the market participants. However, the market model assumes that such expressions of power do not occur; instead trades are always mutually voluntary.

Thus, in a market model, when we assume that market participants accept only mutually voluntary trades, we are also implicitly accepting that the participants refrain from theft, or any sort of coercion, to get their own way. The ethical principle is an acceptance and respect for personal property. Without this, the market may fail.

The belief in a property system and respect for it can arise in several ways. One way for the market to function effectively is to assume adherence to an ethical principle for the acceptance and respect for property claims. These beliefs may be inculcated through a process of religious training (e.g., thou shalt not steal; thou shalt not kill) and enforced with the threat of eternal damnation for serious violators. In this case a person may have a belief in a God given "right" to property and any violation of that right represents a transgression against God.

Secondly though, a property system can be created by the State through the establishment of property laws with enforcement accomplished using a criminal justice system. In this case, a property "right " is established by the State and violations of those rights can result in State penalties.

Note that a property "right" is not absolutely necessary for the market to function; The market could function perfectly if individuals merely accept each others' property claims and agree to avoid force and coercion to benefit themselves. In other words, strict adherence to these ethical principles is sufficient to generate the win-win outcomes from trade. Alternatively though, we could imagine that individuals will not behave ethically and that the State imposes a system of "rights," with its associated enforcements and penalties in order to induce the appropriate behavior. In this latter case, people will be forced into ethicallike behavior because they will seek to avoid the State-imposed penalties. In other words neither a set of ethical principles regarding property or a set of State-established property rights alone are necessary for effective market exchange, but either condition, when perfectly enforced, is sufficient.

\section{The Importance of Honesty}

Another key assumption of the standard market model is that the participants have perfect information about the products for which they are trading, including all features and qualities that can affect their utility. The presence of imperfect information can easily lead to unsatisfactory outcomes and can allow one trader to take advantage of the other.

For example, suppose the oranges that Smith is trading are not of equal quality. Some are not as sweet and have sections that are sour and taste bad. Suppose Smith knows that the lower quality oranges have a slightly different coloration on the outside. He has also discovered that if he coats all the oranges with a dye made from used orange peels then the lower quality oranges will look exactly like the high quality oranges. By keeping accurate information from Jones, Smith is able to trade his oranges at a more favorable terms of trade than otherwise. 
Of course Jones will learn of the quality differences after the trade and that may affect Smith's reputation depending on what he said about the oranges during the bargaining process. Jones may be reluctant to trade with Smith in the future, or he may adjust his trade offers in light of the quality variance. However, Smith's actions could pay off if he believes his interaction with Jones is just a one-time event.

Consider another situation. Suppose that traders are communicating with each other from a distance, relying on verbal or written descriptions of the products being traded but without having an opportunity to examine and check the goods being purchased. In this case there is room for deception again. Indeed one real world problem that regularly arises is that, products once received and paid for turn out not to be at the expected quality level or standard. Alternatively, money may not be received from the buyer after the products have been delivered. Also, products may be advertised in ways that embellish its qualities well beyond its true nature.

All of these situations require a lack of information for at least one of the participants. Clearly, numerous deceptive practices are possible with imperfect or asymmetric information. If the traders truly had perfect knowledge about the products, as is generally assumed in the standard market model, then such deceptions would not occur.

As with property, there are several mechanisms that can assure markets function effectively. One mechanism requires that individuals adhere to a set of ethical principles. If all market participants were always honest, disclosed all pertinent information to each other and always fulfilled promises made to each other, then participants could be assured the perfect information needed to make utility improving trades. Alternatively, if the State imposes laws establishing sanctions against individuals that violate these principles and provide appropriate enforcements, then individuals may be induced to behave ethically. Thus, either a system of ethics or an appropriate system of State-imposed laws and enforcement mechanisms are sufficient conditions for effective market exchange.

Table 1 provides a comparison between the standard way of presenting the assumptions of a pure exchange model and the ethics based set of assumptions. The standard economics description "rules-in" the good outcome. It illustrates what would have to be true to assure mutual gains from trade in a market. The ethics-based set of assumptions, in contrast, "rules-out" the bad outcomes that could arise. They illustrate what could arise if certain ethical norms or institutional enforcements were not applied. Both sets of assumptions are consistent with each other and lead to the same results. 
TABLE 1

COMPARISON OF ASSUMPTIONS IN A PURE EXCHANGE MODEL

\begin{tabular}{|l|l|}
\hline Standard Economics Description & Ethics-Based Description \\
\hline $\begin{array}{l}\text { Traders are self-interested utility- } \\
\text { seekers (maximizers); } \\
\text { Traders accept dependency of trade }\end{array}$ & $\begin{array}{l}\text { Traders are self-interested utility- } \\
\text { seekers (maximizers); } \\
\text { Traders accept dependency of trade }\end{array}$ \\
\hline \multirow{4}{*}{ Trade is mutually voluntary } & $\begin{array}{l}\text { Property rights: Endowments are } \\
\text { owned by the trading agents; } \\
\text { Agents know who owns what }\end{array}$ \\
\cline { 2 - 3 } & $\begin{array}{l}\text { Property rights are respected: } \\
\text { No theft and no damage occurs }\end{array}$ \\
\cline { 2 - 3 } & $\begin{array}{l}\text { Freedom to trade or not trade is } \\
\text { respected: agents do not use force } \\
\text { or threat of force }\end{array}$ \\
\cline { 2 - 3 } & $\begin{array}{l}\text { Personal safety is guaranteed: } \\
\text { Agents do not use force or threat of } \\
\text { force to affect the outcome. }\end{array}$ \\
\hline Homogeneous goods & $\begin{array}{l}\text { No deception; } \\
\text { No lying or cheating occurs; } \\
\text { Promises are fulfilled; } \\
\text { Contracts are enforced } \\
\text { Agents know own preferences } \\
\text { Agents know product qualities }\end{array}$ \\
\hline
\end{tabular}

\section{COMMON MARKET MISUNDERSTANDINGS}

By emphasizing the ethics-based assumptions to students it is possible to clarify some widespread misunderstandings. Consider the following questions that can be used to promote student learning.

Q. Why do economists sometimes contend that self-interest, even greed, is good?

$A$. Because in the context of the standard market model with the assumptions holding, self-interest brings individuals together in a market and creates the surplus value that will accrue to both participants through trade. The desire to better oneself, when pursued under the assumptions of the market mechanism, will also benefit your trading partner. Market exchange is a win-win situation whenever the assumptions are fulfilled.

Q. Why do most people believe that greed is a bad thing that needs to be stamped out?

$A$. Because if self-interest is excessive it may lead agents to deceive, steal, or threaten others in order to achieve a better outcome for themselves, in which case surplus value is not generated for all agents. Instead one agent gains at the expense of the other. This does not occur in the standard market model because it is assumed away with the assumption that market participants adhere to a basic system of ethics or State-enforced regulations. 
Thus, those who applaud the Michael Douglas speech in the movie Wall Street, could be basing their acceptance on one set of assumptions (self-interest that is not excessive and does not cross ethical boundaries), while those who abhor greed and believe it should be stamped out could be basing their view on a different set of assumptions (that self-interest will cross the ethical boundaries and be excessive, i.e., greedy).

Indeed, the ethical system that underpins the market can provide a way to distinguish acceptable selfinterest from excessive self-interest (or greed). Acceptable self- interest includes methods to better oneself while respecting others' property, avoiding theft, deception, threats, the use of coercion and always keeping one's promises. In contrast, greed can be defined as behavior that betters oneself as a result of a violation of any of these same ethical principles. Thus, a Bernie Madoff, convicted of investor fraud, was greedy because he deceived his investors and was unable to fulfill his promises to them, whereas, a Bill Gates was not greedy (only self-interested) when he made billions of dollars by providing a much-desired product to people in the marketplace.

This distinction also helps define a simple set of business ethics. Corporations are often disparaged under the presumption that they will do anything to satisfy their greed for greater profit. It is regularly suggested that the purpose of a corporation is to maximize the return to shareholders. This might be interpreted to mean that corporations may deceive and bribe and cheat their customers in order to improve the bottom line. In this instance though, pursuit of profit is an unethical trait that deserves condemnation.

To say that businesses are greedy presumes that they are not acting ethically; however, by virtue of that, the greedy behavior also violates the constraints of the standard market model. To be consistent with the assumptions of the market model, businesses would have to conform to the ethical principles forbidding theft, deception and threatening behavior. Good business ethics means accepting profit obtained via self-interest while simultaneously rejecting profit obtained via greed (in other words, profit obtained via unethical means).

Q. Which is a more accurate depiction of reality, the market model in which self-interested agents generate social benefits for all, or the world of market critics who believe that greed is an evil that needs to be stamped out?

$A$. Both are right! The world economy consists of an impressive collection of markets that have allowed for trade, and its subsequent specializations, to deliver the most extensive collection of goods and services the world has ever seen. World GDP has grown at a phenomenal rate in the past few hundred years and it is obvious that this could not have happened without the expansion of specialization and trade motivated by self-interest. At the same time, attempts to satisfy greed via force, threat of force, deception, theft, corrupt practices, and other unethical behaviors are also widespread. The ethical assumptions in a market model are clearly not always satisfied. In these cases, greed results in non-market outcomes. The world is both a place where self-interested behavior has promoted science and innovation and created new products that has fueled a phenomenal increase in the world's average standard of living AND a place where excessive greed has led to force, violence, theft, trickery, and dishonesty.

\section{Q. Isn't it true that if unethical behaviors occur in the real world then the model is falsified, or invalid?}

$A$. It is worth highlighting to students that a violation of an assumption of the market model does not mean that the market ceases to work or that the results of the model are falsified. It is clearly true that the assumptions of the model are not always fulfilled in the real world. Theft does exist. Companies do sometimes lie about their products. Information is never perfect. Nevertheless, in many instances the assumptions of the model are fulfilled, or very nearly so.

One could ask students to consider all of the purchases they have made in the past month. These would include purchases of food and clothing, payment for their dorm room, purchases of cell phone and cable TV services, restaurant meals, movie tickets, etc. Then ask to estimate what percentage of these purchases they believe were reasonable; in other words did they receive what they expected and were they pleased to have purchased the products? You might even inquire what percentage were repeat purchases. 
Then ask, in what percentage of these purchases did they feel deceived? Were they robbed during the month? Did they ever feel threatened or feel forced to make a purchase?

Reflections such as these should lead students to conclude that most of their monthly purchases are well informed and result in satisfactory trades that will be repeated regularly over and over again. Most students were not robbed during the month, they were not deceived, they did not feel threatened and they did not feel unsafe in the marketplaces. However, this cannot be said about every market in the world today and it is worth asking students to consider the effects that violence, war, corrupt practices and deceptions might then have on the efficiency of markets and hence the well-being of individuals living in those areas.

The implication is that the market assumptions are fulfilled much of the time in many markets around the world. Perfect enforcement of property rights can assure the mutually advantageous outcome in a market model, but that doesn't mean that markets fail completely if property right enforcement is not perfect. ${ }^{10}$ Instead the usefulness of the model is to highlight why the favorable market outcomes are assured when the ethical assumptions of the model are fulfilled and why unfavorable outcomes can arise when the assumptions are unfulfilled. It also motivates the following question.

Q. What are the institutions that can or do help to promote the ethical behaviors that contribute to favorable market outcomes?

$A$. There are both private mechanisms and public mechanisms that are regularly applied to promote ethical behavior or outcomes in society.

On the private side, the ethical norms of the market are a subset of virtually every society's moral codes. Children around the world are taught not to hurt each other, not to steal, lie, cheat or deceive others and to keep their promises. All of the major world religions include these rules, among others, as principles of behavior that followers should adhere to. If everyone abided by these ethical principles throughout their lives there would be no need for any other interventions. However, despite the cultural and religious pressures, many people fail at one time or another. In modern religions these are often classified as sins that humankind is invariably drawn towards. A good person is one who adheres to the moral code, which includes these ethical principles; to act otherwise is proscribed by the religious codes.

However, perhaps because so many people fail to abide by these principles, societies have developed both private and public mechanisms to control unethical behavior. These mechanisms are costly though. See Table 2.

TABLE 2

MECHANISMS TO ENCOURAGE ETHICAL BEHAVIOR

\begin{tabular}{|l|l|}
\hline Private Mechanisms & Enforcement \\
\hline Family Rules or Norms & Scolding, Punishments, Threats \\
\hline Moral Codes & Social Pressures; Guilt \\
\hline Religious Authority & $\begin{array}{l}\text { Sins, penance, loss of God's favor, } \\
\text { eternal damnation }\end{array}$ \\
\hline Fences, Walls, Door locks, Safes & Security guards, Personal firearms \\
\hline Public Mechanisms & Enforcement \\
\hline Laws; Regulations; Prohibitions & $\begin{array}{l}\text { Judicial System: Sanctions, Fines, } \\
\text { Imprisonment }\end{array}$ \\
\hline $\begin{array}{l}\text { Police Forces; Militias; Military; } \\
\text { Intelligence agencies }\end{array}$ & Use of force or threats of force \\
\hline
\end{tabular}


Personal property protection is accomplished privately when businesses and households erect fences and walls, or install locks, hire guards and install security systems. Individuals may also own firearms with the expressed purpose of protecting their property and providing safety from intruders.

The problem of incomplete information and distrust can be tackled privately in a variety of ways. Businesses have established trading documents such as letters of credit, bills of lading, bank guarantees, and waybills. Businesses can also guarantee the quality that the consumer expects by providing warranties. Websites can allow previous customers to provide testimonials that help to build a company's reputation.

On the public side, state interventions include laws against violence such as those prohibiting murder, assault and rape. There are laws creating property rights and protections against theft of personal property. There are laws against false advertising, and requirements for full disclosure of ingredients through labeling. In addition to laws, there must also be an enforcement mechanism. A police force is used to patrol and catch perpetrators of crimes. A judicial system is used to make fair judgments about wrongdoing. A prison system is used to incarcerate dangerous offenders. As a result, the individual cost of violating the basic ethical principles is increased via these mechanisms and unethical behavior is thereby discouraged.

In total, these mechanisms surely serve to reduce the incidence of violence, theft and deception. Although these efforts, laws and institutions do not eliminate the unethical behavior, the reduction of the incidence should raise the incentives for individuals to cooperate with each other and come together in markets to trade. Indeed one could hypothesize that the reason these ethical norms arose in early human society was precisely because they promoted the mutual advantages that can arise from trade. In other words, these ethical principles may have developed in human society because cooperation promotes favorable market trading and thereby improves the well-being of the species (James, 2010).

\section{CONCLUSION}

This paper offers a method for introducing the ethics of markets to principles of economics students. The approach uses an Edgeworth box diagram describing a pure exchange market to demonstrate how certain ethical principles, such as the respect for property, the fulfillment of promises, and the avoidance of deception, threats and violence against others, help to assure the favorable win-win outcome that arises whenever trade, or exchange, occurs.

It is important to emphasize the ethical foundations for market effectiveness because too many people believe that the economic man described in models, often called homo economicus, is both greedy and amoral. This has created a false impression, frequently accentuated in the plots of Hollywood movies, that economic and business behavior is always wrong.

One way to counter these false impressions is via instruction when students first begin to learn about economics, that is, in introductory microeconomics courses. The most popular economics principles textbooks today barely mention the importance of the core set of ethics sufficient to sustain a market economy. Nor do most popular texts emphasize the importance of the social, religious and government institutions that have evolved to inhibit unethical behavior. If the economics discipline does not teach these principles at the very beginning, then it is little wonder that the popular false impressions are sustained.

The illustration of these ethical principles using the pure exchange model is also conducive to explaining the functionality of models to new students of economics. Too often students think that economic models are meant to be true reflections of the real world. That can lead to a belief that if economic models seem unrealistic then they cannot generate a better understanding of the real world. However, models are simplifications of the real world and thus by definition will have assumptions that are unrealistic.

In the pure exchange model we can question the verity of many of the assumptions including utility maximization, perfect knowledge of preferences, perfect information about the quality of the goods, among others. Translated into the ethical terms, it is easy to doubt that theft, and threats of violence, and 
deceptive practices, do not occur in the real world. Nonetheless, the usefulness of the model arises by comparing what would happen when the ethical and other assumptions are fulfilled, to what would happen when the assumptions are relaxed, or not fulfilled. When the assumptions do not hold we can say there are market imperfections, or market failure. With this model, students can learn how much more effective market outcomes will be if participants conform to the ethical principles because they will see explicitly what can happen when they are not fulfilled. Students can also be taught how religious and political institutions have developed and are applied to mitigate the problems that arise with these particular market imperfections.

\section{ENDNOTES}

1. The author is thankful for support from the GW Institute for International Economic Policy and for research assistance from Jacob Burman.

2. See this online discussion about economist's opinions about greed. http://evonomics.com/do-economistactually-believe-greed-is-good/

3. Carlin, Wendy, Financial Times Opinion, "Economics explains our world - but economics degrees don't," 17 Nov, 2013.

4. Also see Henrich et.al, (2001) for a demonstration of alternative economic motives.

5. The textbooks reviewed include Baumol \& Blinder (2015), Besanko et.al. (2011), Case et.al. (2014), Frank, et.al. (2013), Hubbard \& O’Brian (2015), Krugman \& Wells (2013), Mankiw (2015),McConnell et.al. (2011), O'Sullivan et.al. (2014), and Parkin (2014).

6. See in particular Carlin et.al. (2014), Chapter 5 on Property, Contract and Power.

7. Nash (1950), and Harsanyi (1956) are two of many papers on this issue.

8. Edgeworth (1881) noted that self-interest can result in two actions. The cooperative action he labeled contract and the uncooperative action he labeled war.

9. This argument is made by Coleman (1987) attributing the idea originally to Frank Knight.

10. Fukuyama (2011) argues that property rights need not be perfect, but rather need to be "good enough" to foster the development of markets.

\section{REFERENCES}

Ben-Ner, A. and Putterman, L. (1998). "Homo Economicus Meets "The Moral Animal": On Some Implications of Evolutionary Psychology," working paper, http://www.econ.brown.edu/fac/Louis_Putterman/working/pdfs/wrirev98.pdf.

Baumol, W. J. and Blinder, A.S. (2012). Macroeconomics: Principles \& Policy. 12th ed. Mason, OH: Cengage Learning, Print.

Besanko, D., Braeutigam, R.R. and Gibbs, M. (2011). Microeconomics. 4th ed. Hoboken, NJ: John Wiley, Print.

Carlin, W, Bowles, S. and Landerretche, O. (2014). The Economy. London: CORE Project, Print.

Case, K. E., Fair, R.C. and Oster, S.M. (2014). Principles of Microeconomics.. 11th ed. Upper Saddle River, NJ: Prentice Hall, Print.

Coleman, J. L. (1985). Market contractarianism and the unanimity rule. Social Philosophy and Policy, 2, (02), 69-114.

Coleman, J. L. (1987). Competition and Cooperation. Ethics, 98, (1), 76-90.

Edgeworth F.Y., (1881). Mathematical Psychics: An Essay on the Application of Mathematics to the Moral Sciences, C. Kegan Paul and Co., London.

Frank, R.H., Bernanke, B. and Johnston, L. (2013). Principles of Microeconomics. 19th ed. New York, NY: McGraw-Hill/Irwin, Print.

Fukuyama, F. (2011). The Origins of Political Order: From Pre-human Times to the French Revolution, Farrar, Straus and Giroux.

Harsanyi, J.C. (1956). Approaches to the Bargaining Problem Before and After the Theory of Games: A Critical Discussion of Zeuthen's, Hicks', and Nash's Theories, Econometrica, 24, (2), 144-157. 
Henrich, J., Boyd, R., Bowles, S., Camerer, C., Fehr, E., Gintis, H., \& McElreath, R. (2001). In search of homo economicus: behavioral experiments in 15 small-scale societies. American Economic Review, 73-78.

Hubbard, R.G. and O'Brien, A.P. (2015) Microeconomics. 5th ed. Upper Saddle River, NJ: Prentice Hall, Print.

James, S.M. (2010). An Introduction to Evolutionary Ethics, Wiley.

Krugman, P. and Wells, R.. (2013). Microeconomics. 3rd ed. New York, NY: Worth, Print.

Mankiw, N.G. (2015). Principles of Microeconomics. 7th ed. Stamford, CT: Cengage Learning, Print.

McConnell, C.R., Brue, S.L. and Flynn, S.M. (2011). Microeconomics. 19th ed. New York, NY: McGraw-Hill Education - Europe, Print.

Nash Jr., J.F. (1950). The Bargaining Problem, Econometrica, 18, (2), 155-162.

O'Sullivan, A., Sheffrin, S.M. and Perez, S.J. (2014). Microeconomics: Principles, Applications, and Tools. 8th ed. Boston, MA: Pearson.

Parkin, M. (2014). Economics. 11th ed. Boston, MA: Pearson, Print.

Skaperdas, S. (2003). Restraining the genuine homo economicus: Why the economy cannot be divorced from its governance. Economics \& Politics, 15, (2), 135-162.

Snower, D. (2014). The Looming Death of Homo Economicus, Project Syndicate, http://www.projectsyndicate.org/commentary/dennis-j--snower-insists-that-humans--economic-self-interest-cannotbe-separated-from-their-capacity-for-care

Ubel, P. (2014). Is Homo Economicus A Psychopath?, Forbes, Dec. 15, 2014.

http://www.forbes.com/sites/peterubel/2014/12/15/is-homo-economicus-a-psychopath/ 